\title{
Adherence and factors related to acceptance of alcohol for antiseptic hand rubbing among nursing professionals*
}

\author{
Adesão e fatores relacionados à aceitação do álcool para fricção \\ antisséptica das mãos entre profissionais da enfermagem \\ Adhesión y factores relacionados con la aceptación del alcohol para fricción \\ antiséptica de las manos entre profesionales de enfermería
}

Adriana Cristina de Oliveira ${ }^{1}$, Camila Sarmento Gama ${ }^{1}$, Adriana Oliveira de Paula ${ }^{1}$

How to cite this article:

Oliveira AC, Gama CS, Paula AO. Adherence and factors related to acceptance of alcohol for antiseptic hand rubbing among nursing professionals. Rev Esc Enferm USP. 2017;51:e03217. DOI: http://dx.doi.org/10.1590/S1980-220X2016037803217

* Extracted from the thesis "Impacto da estratégia multimodal na adesão a higiene de mãos entre a equipe multiprofissional", Escola de Enfermagem, Universidade Federal de Minas Gerais, 2015.

${ }^{1}$ Universidade Federal de Minas Gerais, Escola de Enfermagem, Belo Horizonte, MG, Brasil.

\section{ABSTRACT}

Objective: Identify rates of adhesion and related factors to acceptance of an alcohol based preparation to hands antiseptic friction among nursing professionals in a unit of intensive therapy. Method: A cross-sectional study, which involved direct observation of hand hygiene opportunities and nursing professionals' completion of questionnaires, was conducted at a university hospital between January and July 2015. Descriptive and univariate analyses were performed, with a 5\% significance level. Results: It was observed 956 opportunities of hand hygiene among 46 nursing professionals. The rate of adhesion to alcohol-based handrub $(\mathrm{ABH})$ was $34.8 \%$ and about $87.0 \%$ preferred handwashing. Nurses used ABH more frequently than nursing technicians $(p<0.001)$, and the report of feeling of clean hands after using the alcohol product was directly related to higher rates of adherence to antiseptic friction through observation $(\mathrm{P}<0.05)$. Conclusion: The finding indicating low $\mathrm{ABH}$ usage highlights the need for greater institutional investment in strategies that help health professionals to recognize the advantages of this type of $\mathrm{HH}$ with respect to time spent, ease of access to dispensers, effectiveness in eliminating microorganisms, and maintaining skin moisturization.

\section{DESCRIPTORS}

Hand Disinfection; Ethanol; Anti-Infective Agents, Local; Health Personnel. 


\section{INTRODUCTION}

Hand hygiene $(\mathrm{HH})$ is recognized as one of the main control measures for healthcare-associated infections $(\mathrm{HAI})^{(1)}$. However, worldwide rates of adherence to $\mathrm{HH}$ guidelines rarely exceed $50 \%{ }^{(2-3)}$. In consideration of this issue, the World Health Organization (WHO) and other national and international institutions developed approaches to improve healthcare professionals' $\mathrm{HH}$ practices ${ }^{(1)}$. The following approaches were highlighted: the "Clean care is safe care" global challenge, the "Clean hands save lives" and "My five moments for $\mathrm{HH}$ " campaigns, and the "Multimodal HH improvement strategy" $(1)$.

These strategies draw attention to the strong recommendation to use alcohol-based handrub $(\mathrm{ABH}$; an alcohol-based preparation), rather than handwashing (soap and water), in $\mathrm{HH}$ when there is no visible dirt on the hands. This recommendation was made because healthcare workers are prone to skin disease for many reasons, frequent hand washing is one of them and allergic contact dermatitis due to alcohol-based handrubs is not very common. $\mathrm{ABH}$ causes less skin dryness, requires only approximately one third of the time to perform, and is more effective in eliminating microorganisms, relative to soap and water, when the hands are visibly clean ${ }^{(1,4)}$.

Other measures should be considered to reduce the risk of developing occupational skin disease as using gloves only for as long as necessary; washing visibly soiled hands with soap and water; and applying moisturizer mainly at the end of the day ${ }^{(1,4-5)}$.

With respect to healthcare professionals' adherence to use this type of $\mathrm{HH}$ procedure, some international studies indicate an increasing trend in using $\mathrm{ABH}$ in practice ${ }^{(3-4)}$. However, in other studies, including Canadian Overall, respondents indicated a statistically significant preference for soap and water over $\mathrm{ABH}^{(4)}$.

The reasons for this choice vary and include the feeling that hands are clean after using soap and water in $\mathrm{HH}$, low tolerance of the alcohol-based product offered by the institution, lack of knowledge/training, behavioral and cultural factors, and institutional safety culture ${ }^{(1,4,6-8)}$.

Intensive Care Units (ICU) are critical sectors where is common the occurrence of HAI, including bacterial resistance, because of the quantity of invasive procedures performed and frequent use of antimicrobials. In these scenarios $\mathrm{HH}$ are essential to assure patient safety ${ }^{(9)}$.

In ICU nursing professionals are those who keep direct contact with patients, being responsible for the greatest majority of health care ${ }^{(10)}$. In this sense, these professionals are the ones who have the highest number of $\mathrm{HH}$ opportunities during work shift.

Therefore, in consideration of the importance of $\mathrm{HH}$ in ICU by nursing professionals and the WHO recommendation for $\mathrm{ABH}$ use, this study aimed to identify rates of adhesion and related factors to acceptance of an alcohol based preparation to hands antiseptic friction among nursing professionals in a unit of intensive therapy.

\section{METHOD}

This cross-sectional study was conducted in a large, tertiary university hospital in Belo Horizonte, Minas Gerais, Brazil. The project was approved by the research ethics committee and conducted in accordance with the National Council Resolution for Research with Human Subjects (CAAE: 18477913.1.0000.5149).

The hospital has two ICU (one for adults and one for children), which had 20 e 14 beds each, respectively. The study participants were all nursing professionals who provided direct patient care in intensive care units, agreed to participate in the study, signed consent forms and were available in data collection dates.

Data were collected via direct observation of $\mathrm{HH}$ opportunities and nursing professionals' completion of questionnaires between January and July 2015. It should be noted that these two collection steps occurred independently and were performed by different researchers, to minimize the Hawthorne effect. To minimize bias it was developed a $\mathrm{HH}$ observation using multiple trained researcher volunteers capable of accurately measuring $\mathrm{HH}$ behavior as corroborated by Linam et al. ${ }^{(11)}$. After observation of nursing professional, they were invited to give their consent and sign the Term of Informed Consent.

Data collection was done by application of a questionnaire followed by direct observation of nursing professionals. Participants completed the Questionnaire for Evaluation of Resistance and Acceptance of the Alcohol-Based Preparation in Use for Hand Hygiene, which was developed by WHO and consisted of questions pertaining to professionals' skin characteristics, self-reported adherence to $\mathrm{HH}$, type of $\mathrm{HH}$ procedure performed most frequently, opinion regarding the alcohol-based product in use at the institution, and factors that could facilitate or hinder adherence to $\mathrm{HH}^{(12)}$.

In the second step, the observation of $\mathrm{HH}$ opportunities involved a structured instrument pertaining to the type of $\mathrm{HH}$ procedure performed ( $\mathrm{ABH}$ or handwashing) and the opportunity to practice $\mathrm{HH}$ according to the Five Moments for $\mathrm{HH}$ proposed by the $\mathrm{WHO}^{(13)}$. Each professional was observed until reach the minimum of 20 opportunities of $\mathrm{HH}$ for at least 20 minutes each session as recommended by $\mathrm{WHO}^{(1)}$.Adherence to $\mathrm{ABH}$ use was calculated as follows:

Adherence to $\mathrm{ABH}$ use $=$ number of times the professional performed handrubbing/number of times the professional performed $\mathrm{HH}$ procedures $\times 100$.

Data were tabulated and analyzed using the Statistical Package for the Social Sciences (SPSS) version 19.0. Descriptive and univariate analyses were performed using Student's $\mathrm{t}$ test and a one-way ANOVA. The significance level was set at $p<.05$ for all analysis, and 95\% confidence intervals were calculated.

\section{RESULTS}

It was observed $956 \mathrm{HH}$ opportunities among 46 nursing professionals included in the study. Most participants were women (84.8\%), 17 (37.0\%) were nurses and 29 (63.0\%) 
were nursing technicians. With regard to work shifts, 19 (41.3\%), 14 (30.4\%), and 13 (28.3\%) participants worked morning, afternoon, and night shifts, respectively.

The adherence rate was of $19.3 \%$. Of the $\mathrm{HH}$ actions performed, $34.8 \%$ and $63.2 \%$ corresponded to $\mathrm{ABH}$ and simple cleaning, respectively. In total $184 \mathrm{HH}$ were performed.

The independent variables explaining nursing professionals' adherence to $\mathrm{ABH}$ use are presented in Table 1.

Table 1 - Rates of adherence to alcohol-based handrub use in nursing staff according to reported characteristics ( $\mathrm{HH}$ performed among 46 nursing professionals included) - Belo Horizonte, Minas Gerais, Brazil, 2015.

\begin{tabular}{|c|c|c|}
\hline Variable & $\begin{array}{l}\text { Rate of adherence to } \\
\text { alcohol-based handrub } \\
\text { use }(\%)(\mathrm{N}=184)\end{array}$ & $p$ value \\
\hline \multicolumn{3}{|l|}{ Professional category } \\
\hline Nurse & 64.1 & \multirow{2}{*}{.000} \\
\hline Nursing technician & 17.8 & \\
\hline \multicolumn{3}{|l|}{ Shift } \\
\hline Day & 37.5 & \multirow{2}{*}{.434} \\
\hline Night & 28.2 & \\
\hline \multicolumn{3}{|l|}{ Employment } \\
\hline Contracted & 39.8 & \multirow{2}{*}{.070} \\
\hline Permanent & 19.2 & \\
\hline \multicolumn{3}{|l|}{ Frequency of moisturizer use } \\
\hline Always or several times per day & 39.9 & \multirow{2}{*}{.571} \\
\hline Rarely or never & 33.1 & \\
\hline \multicolumn{3}{|l|}{ Atopic dermatitis } \\
\hline Yes & 42.6 & \multirow{2}{*}{.269} \\
\hline No & 34.5 & \\
\hline \multicolumn{3}{|c|}{ Attribution of skin characteristics to the product } \\
\hline Yes & 36.6 & \multirow{2}{*}{.020} \\
\hline No & 16.4 & \\
\hline \multicolumn{3}{|c|}{ Feeling of having clean hands after rubbing } \\
\hline Yes & 35.7 & \multirow{2}{*}{.049} \\
\hline No & 18.6 & \\
\hline \multicolumn{3}{|c|}{ Frequency of $\mathrm{HH}$ practice during the work shift } \\
\hline $0-15$ times & 22.2 & \multirow{2}{*}{.108} \\
\hline$\geq 16$ times & 37.9 & \\
\hline \multicolumn{3}{|l|}{ HH product preference } \\
\hline Soap and water & 33.5 & \multirow{2}{*}{.667} \\
\hline Alcohol-based solution & 38.9 & \\
\hline
\end{tabular}

$\mathrm{HH}=$ hand hygiene

Note: $(\mathrm{N}=184)$.

As shown in Table 1, the professional category showed a statistically significant difference in $\mathrm{ABH}$ use, indicating that the nurses used $\mathrm{ABH}$ more often comparing to nursing technicians $(p=.000)$. However, participants who attributed their skin characteristics to the use of the alcoholbased product and reported a feeling of having clean hands after using $\mathrm{ABH}$ exhibited greater adherence to $\mathrm{ABH}$ use $(p=.010$ and $p=.049$, respectively).
Table 2 describes the results of the mean rate of adherence to $\mathrm{ABH}$ use for each evaluation variable. Nursing professionals evaluated the characteristics on the alcoholbased product used in the institution by assigning scores ranging from 1 to 3 (1: unpleasant, 2: average, and 3: pleasant). According to it $45.8 \%$ of nursing professionals who adhered to $\mathrm{ABH}$, thought that irritation caused by the product was unpleasant.

Table 2 - Rate of adherence to alcohol-based handrub use in nursing staff according to their responses regarding product characteristics - Belo Horizonte, Minas Gerais, Brazil, 2015.

\begin{tabular}{lcccc}
\hline \multicolumn{5}{c}{ Rate of adherence to alcohol-based handrub use (\%) } \\
\hline Variable & Unpleasant, 1 & Average, 2 & Pleasant, 3 & $p$ value* \\
\hline Color & - & 33.5 & 35.1 & .235 \\
Odor & - & 36.3 & 32.1 & .223 \\
Irritation & 45.8 & 36.3 & 21.3 & .077 \\
Dryness & 37.2 & 31.3 & 6.36 & .139 \\
Drying speed & 0.0 & 43.5 & 29.9 & .298 \\
Ease of use & 0.0 & 23.2 & 37.2 & .103 \\
Application & 17.8 & 37.8 & 32.9 & .224 \\
General evaluation & 35.6 & 28.6 & 33.9 & .326 \\
\hline
\end{tabular}

*One way ANOVA test

Note: $(\mathrm{N}=46)$

None of the participants' responses regarding the characteristics of the alcohol-based product exerted a statistically significant effect on adherence to $\mathrm{ABH}$ use, but it was verified that nursing professionals' who evaluated the alcoholic product as unpleasant regarding skin irritation, dryness and general evaluation, were the professionals with greatest adherence rates to the product.

With respect to moisturizer use during care activities, 12 (26.1\%) participants reported using it always or several times per day, and 34 (74.9\%) reported using it once per day, rarely, or never. The participants identified their hands as dry (80.4\%), rough $(6.5 \%)$, or injured or peeling $(4.3 \%)$. In addition, $89.1 \%, 15.2 \%, 6.5 \%$, and $2.2 \%$ of participants attributed these characteristics to the use of an alcohol-based solution, the use of gloves, frequency of $\mathrm{HH}$ practice, and the type of solution used, respectively. Despite this finding, no participants reported an intolerance to the alcohol-based product used in the institution; however, seven (15.2\%) reported having atopic dermatitis.

Regarding the number of times $\mathrm{HH}$ was performed, 25 (54.3\%) nursing professionals reported cleaning their hands more than 21 times during a 6-hour shift, and the selfreported mean rate for adherence to $\mathrm{HH}$ recommendations was $91.2 \%$ (range: $70-100 \%$ ). Most participants (87.0\%) reported a feeling of having clean hands after using $\mathrm{ABH}$; however, 40 (87.0\%) preferred handwashing. Nursing professionals evaluated the characteristics of the alcohol-based product used in the institution by assigning scores ranging from 1 to 3 (1: unpleasant, 2: average, and 3: pleasant; Table 3$)$. In addition, most participants (95.7\%), including the 13 nursing professionals who reported $100 \%$ adherence rates, believed that they could improve their $\mathrm{HH}$ adherence rates. 
Table 3 - Nursing professionals' perceptions regarding the characteristics of the alcohol-based product used in $\mathrm{HH}$ practice at the institution - Belo Horizonte, Minas Gerais, Brazil, 2015

\begin{tabular}{lccc}
\hline Characteristic & $\begin{array}{c}\text { Unpleasant, } \\
(\%)\end{array}$ & $\begin{array}{c}\text { Average, 2 } \\
(\%)\end{array}$ & $\begin{array}{c}\text { Pleasant, 3 } \\
(\%)\end{array}$ \\
\hline Color & 2.2 & 56.5 & 39.1 \\
Smell & 2.2 & 45.7 & 50.0 \\
Irritation & 23.9 & 39.1 & 34.8 \\
Dryness & $\mathbf{6 3 . 0}$ & 28.3 & 6.5 \\
Drying speed & 2.2 & $\mathbf{6 0 . 9}$ & 34.8 \\
Ease of use & 4.3 & 15.2 & 78.3 \\
Application & 8.7 & 37.0 & 52.2 \\
General evaluation & 13.0 & 13.0 & 71.7 \\
\hline
\end{tabular}

Note: $(\mathrm{N}=46)$

The main factors reported to hinder greater adherence to $\mathrm{HH}$ were related to materials (such as the availability and quality of materials and distance from sinks; 84.8\%), training (including lectures and reminders in the workplace; $13.0 \%$ ), work overload (28.3\%), and colleagues' failure to adhere to $\mathrm{HH}(2.2 \%)$.

\section{DISCUSSION}

The results of the comparison of the characteristics evaluated and rates of adherence to $\mathrm{ABH}$ use showed that being a nurse, attributing hand characteristics (dry, rough, damaged, or peeling) to the use of the alcohol-based solution, and the feeling of having clean hands after $\mathrm{ABH}$ use exerted a positive influence on alcohol-based solution use. Consistent with the current findings, a similar study showed that professionals who considered alcohol effective and easy to use and had good skin tolerance and a feeling of clean hands after use reported using $\mathrm{ABH}$ more frequently relative to handwashing ${ }^{(14)}$. However, there is a methodological difference between these studies, in that the work cited used self-reported rates of adherence, while the current study used rates derived from direct observation of nursing professionals.

Self-reported rates could be subject to the provision of socially acceptable responses, which do not always reflect reality, limiting the findings. In most cases, self-reported rates reflect health professionals' intentions regarding $\mathrm{HH}$ or the belief that their $\mathrm{HH}$ adherence is good, rather than representing their actual $\mathrm{HH}$ adherence rates ${ }^{(2,15-16)}$.

In this study, the nursing professionals' self-reported adherence rate was high, but the observed rate was low, which supports the position that self-report rates should be evaluated with caution. Furthermore, the trend in overestimation of self-report rates is reinforced by the finding that professionals who reported adherence rates of 100\% stated that they believed that it was possible to improve their $\mathrm{HH}$ adherence.

Most nursing professionals who participated in the study did not use moisturizer during care activities; this finding was inconsistent with those of other studies, in which professionals reported using moisturizers ${ }^{(15)}$. The use of moisturizer is strongly recommended by the WHO, because of the need to avoid skin dryness and irritation and provide a protective barrier against the irritating properties of $\mathrm{HH}$ products $^{(1)}$. The use of moisturizers should be encouraged by the institution, mainly because most professionals reported dry hands. However, the fact that sharing moisturizers is contraindicated and individual use is advised.

Most nursing professionals did not report dermatitis or intolerance to alcohol-based products, which is consistent with other results reported in the literature ${ }^{(15)}$. This suggests that professionals should exhibit greater adherence to alcohol-based preparation use because of good tolerance to these products.

The finding that nursing professionals reported the feeling of having clean hands after using the alcohol-based solution and considered it pleasant is positive. This highlights the importance of using solutions that are accepted well by healthcare professionals.

With respect to the quality of alcohol-based solutions, the findings suggest that they should have no fragrance and a low potential for irritation; contain moisturizing cream to prevent drying; provide the feeling of having clean hands; and most importantly, be effective against microorganisms and dispensed in single measures by devices with pre-established units ${ }^{(1)}$.

The finding that nursing professionals believed that they could improve their $\mathrm{HH}$ adherence could indicate additional concern for their own safety and that of the patients in their care, which should be emphasized and considered a positive factor in efforts to improve care practices.

With respect to the factors that hindered $\mathrm{HH}$, it should be noted that they were consistent with those reported in the literature, which were generally related to professional category, physical and structural factors, material resources, knowledge, beliefs, goals, memory, attention, and decision making ${ }^{(6,8,17-18)}$. The type of $\mathrm{HH}$ procedure (simple cleaning or $\mathrm{ABH}$ ) used most frequently by professionals varies according to country, study type, and intervention ${ }^{(19-21)}$. In Brazil, professionals used soap and water more frequently, instead of alcohol-based products, with rates of over $90 \%{ }^{(20)}$. Similar findings were reported for nursing and medical students in Turkey and Italy ${ }^{(21)}$.

Nevertheless, after participating in interventions designed to improve $\mathrm{HH}$, professionals tend to exhibit increased adherence to $\mathrm{ABH}$ use ${ }^{(19,22)}$. They are generally more likely to use handwashing, particularly in developing countries and those with a tropical climate, because of the feeling of having clean hands ${ }^{(1)}$. Consistent with this finding, most of the nursing professionals in the current study who reported a feeling of having clean hands after using the alcohol-based solution exhibited higher rates of adherence to $\mathrm{ABH}$ use.

Liquid soap is recommended for hands visibly dirty; however, when there is no dirt, handrubbing using alcoholbased products is recommended because of its effectiveness, low cost, short application time, and high skin tolerance ${ }^{(1,23)}$. Therefore, the practice of cleaning via handrubbing using alcohol-based products should be encouraged, with consideration of the specific indications for each type of cleaning. 
In this context, it is suggested the provision of alcohol-based preparations in visible and accessible locations at points of care. The WHO advises that dispensers for alcohol-based hand rubs should be available adjacent to each patient's bed and at many other points of care ${ }^{(1,12,24)}$. As the same this measure is mandatory in Brazil since 2010 through Brazilian legislation, Brazilian Board Resolution (Resolução da Diretoria Colegiada) 42 in all health services, regardless of their complexity ${ }^{(23)}$.

Health professionals' replacement of handwashing with the $\mathrm{ABH}$ technique is a complex process that involves behavior change, extrapolating personal context and work processes. This procedure is time consuming, and implementation can be slow depending on the institution's organizational structure, investment in continuing education for professionals, and promotion of effectiveness and adherence.

As limitation of this study, it can be noted that the prospective follow-up is prone to subject replacements, expressed by losses for several reasons, such as vacation, absenteeism, health licenses and layoffs during the data collection. Besides that, the study was carried out in a unique Brazilian health institution only with nursing professionals.

\section{CONCLUSION}

The results showed that the adherence to antiseptic friction among nursing professionals assessed was low, and factors that influenced greater adherence to $\mathrm{ABH}$ use included being a graduated nurse, attribution of hand characteristics to the use of $\mathrm{ABH}$ preparations, and the feeling of having clean hands after using the alcohol-based solution. Although none of the nursing professionals reported intolerance to the alcohol-based product, some characteristics influenced rates of adherence to its use.

However, it should be noted that low adherence rates for this type of $\mathrm{HH}$ procedure could be directly related to a need for greater institutional investment in strategies to help health professionals to recognize the advantages of handrubbing with alcohol-based products, such as needing less time to clean hands, ease of access to dispensers, effective microorganism elimination, and maintenance of skin moisturization.

\section{RESUMO}

Objetivo: Identificar as taxas de adesão e os fatores relacionados à aceitação do produto alcoólico para fricção antisséptica das mãos entre profissionais da enfermagem de uma unidade de terapia intensiva. Método: Foi realizado um estudo transversal, que envolveu a observação direta de oportunidades de higienização das mãos e o preenchimento de questionários pelos profissionais de enfermagem, em um hospital universitário, entre janeiro e julho de 2015. As análises descritivas e univariadas foram realizadas, com um nível de significância de 5\%. Resultados: Foram observadas 956 oportunidades de higiene das mãos entre 46 profissionais de enfermagem. A taxa de adesão à fricção antisséptica foi de $34,8 \%$ e cerca de $87,0 \%$ profissionais relataram preferir a higiene de mãos simples. Enfermeiros realizaram a fricção antisséptica com mais frequência que os técnicos de enfermagem $(\mathrm{p}<0,001)$, e o relato da sensação de ter as mãos limpas após o uso do produto alcoólico esteve diretamente relacionado a taxas mais altas de adesão à fricção antisséptica por meio da observação direta $(p<0,05)$. Conclusão: A baixa adesão à fricção antisséptica encontrada aponta para a necessidade de maior investimento da instituição em estratégias que subsidiem os profissionais de saúde a reconhecer as vantagens desse tipo de higiene de mãos quanto ao tempo dispendido, à facilidade de acesso aos dispensadores e, sobretudo, à sua efetividade na eliminação de microrganismos e manutenção da pele hidratada.

\section{DESCRITORES}

Desinfecção das Mãos; Etanol; Anti-Infecciosos Locais; Pessoal de Saúde.

\section{RESUMEN}

Objetivo: Identificar las tasas de adhesión y los factores relacionados con la aceptación del producto alcohólico para fricción antiséptica de las manos entre profesionales de enfermería de una unidad de cuidados intensivos. Método: Se llevó a cabo un estudio transversal, que involucró la observación directa de oportunidades de higienización de las manos y el llenado de cuestionarios por los profesionales de enfermería, en un hospital universitario, entre enero y julio de 2015. Los análisis descriptivos y univariados fueron realizados con un nivel de significación del 5\%. Resultados: Se observaron 956 oportunidades de higiene de las manos entre 46 profesionales de enfermería. La tasa de adhesión a la fricción antiséptica fue del 34,8\% y un 87,0\% de los profesionales relataron preferir la higiene de manos simple. Enfermeros realizaron la fricción antiséptica con más frecuencia que los técnicos de enfermería ( $p<; 0,001)$, y el relato de la sensación de tener las manos limpias tras el uso del producto alcohólico estuvo directamente relacionado con tasas más altas de adhesión a la fricción antiséptica por medio de la observación directa $(\mathrm{p}<; 0,05)$. Conclusión: La baja adhesión a la fricción antiséptica encontrada señala hacia la necesidad de mayor inversión de la institución en estrategias que subsidien los profesionales sanitarios a reconocer las ventajas de ese tipo de higiene de manos en cuanto al tiempo empleado, la facilidad de acceso a los dispensadores y sobretodo su efectividad en la eliminación de microorganismos y mantenimiento de la piel humectada.

\section{DESCRIPTORES}

Desinfección de las Manos; Etanol; Antiinfecciosos Locales; Personal de Salud.

\section{REFERENCES}

1. World Health Organization. WHO guidelines on hand hygiene in health care - First global patient safety challenge clean care is safer care. Geneva: WHO; 2009.

2. Alsubaie S, Maither AB, Alalmaei W, Al-Shammari AD, Tashkandi M, Somily AM, et al. Determinants of hand hygiene noncompliance in intensive care units. Am J Infect Control. 2013;41(2): 131-5. 
3. Chen JK, Wu KS, Lee SS, Lin HS, Tsai HC, Li CH, et al. Impact of implementation of the World Health Organization multimodal hand hygiene improvement strategy in a teaching hospital in Taiwan. Am J Infect Control. 2016;44(2):222-7

4. Kirk J, Kendall A, Marx JF, Pincock T, Young E, Hughes JM, et al. Point of care hand hygiene-where's the rub? A survey of US and Canadian health care workers'knowledge, attitudes, and practices. Am J Infect Control. 2016;44(10):1095-101.

5. Campion, K. Don't forget hand care when promoting hand hygiene in hospitals. BMJ. 2015;351:h4436.

6. Oliveira AC, Paula AO. Factors related to poor adherence to hand hygiene in healthcare delivery: a reflection . Ciênc Cuidado Saúde. 2014;13(1):185-9.

7. McLaughlin AC, Walsh F. Self-reported reasons for hand hygiene in 3 groups of health care workers. Am J Infect Control. 2012;40(7):653-8.

8. Squires JE, Linklater S, Grimshaw JM, Graham ID, Sullivan K, Bruce N, et al. Understanding practice: factors that influence physician hand hygiene compliance. Infect Control Hosp Epidemiol. 2014;35(12):1511-20.

9. Tajeddin E, Rashidan M, Razaghi M, Javadi SS, Sherafat SJ, Alebouyeh M, et al. The role of the intensive care unit environment and healthcare workers in the transmission of bacteria associated with hospital acquired infections. J Infect Public Health 2016; 9(1):13-23.

10. Novaretti MCZ, Santos EV, Quitério LM, Daud-Gallotti RM. Sobrecarga de trabalho da Enfermagem e incidentes e eventos adversos em pacientes internados em UTI. Rev Bras Enferm. 2014;67(5):692-9.

11. Linam WM, Honeycutt MD, Gilliam CH, Wisdom CM, Bai S, Deshpande JK. Successful development of a direct observation program to measure health care worker hand hygiene using multiple trained volunteers. Am J Infect Control. 2016; 44(5):544-7.

12. World Health Organization. Hand hygiene technical reference manual: to be used by health-care workers, trainers and observers of hand hygiene practices. Geneva: WHO; 2009.

13. World Health Organization. Guide to implementation: a guide to the implementation of the WHO multimodal hand hygiene improvement strategy. Geneva: WHO; 2009.

14. Tavolacci MP, Merle V, Pitrou I, Thillard D, Serra V, Czernichow P, et al. Alcohol-based hand rub: influence of healthcare workers' knowledge and perception on declared use. J Hosp Infect. 2006;64(2):149-55.

15. Chamorey E, Marcy PY, Dandine M, Veyres P, Negrin N, Vandenbos F, et al. A prospective multicenter study evaluating skin tolerance to standard hand hygiene techniques. Am J Infect Control. 2011;39(1): 6-13.

16. Borg MA, Benbachir M, Cookson BD, Redjeb SB, Elnasser Z, Rasslan O, et al. Self-protection as a driver for hand hygiene among healthcare workers. Infect Control Hosp Epidemiol. 2009;30(6):578-80.

17. Contzen N, Mosler HJ. Identifying the psychological determinants of handwashing: results from two cross-sectional questionnaire studies in Haiti and Ethiopia. Am J Infect Control. 2015;43(8):826-32.

18. Smiddy MP, O' Connell R, Creedon SA. Systematic qualitative literature review of health care workers' compliance with hand hygiene guidelines. Am J Infect Control. 2015;43(3):269-74.

19. Salmon S, Truong AT, Nguyen VH, Pittet D, Mclaws ML. Health care workers' hand contamination levels and antibacterial efficacy of different hand hygiene methods used in a Vietnamese hospital. Am J Infect Control. 2014;42(1):178-81.

20. Bathke J, Cunico PA, Maziero ECS, Cauduro FLF, Sarquis LMM, Cruz EDA. Infrastructure and adherence to hand hygiene: challenges to patient safety. Rev Gaúcha Enferm. 2013;34(2):78-85.

21. Gül A, Üstündağ $H$, Zengin N. Assessing undergraduate nursing and midwifery students' compliance with hand hygiene by self-report. Int J Nurs Pract. 2012;18(3): 275-80.

22. Barrera L, Zingg W, Mendez F, Pittet D. Effectiveness of a hand hygiene promotion strategy using alcohol-based handrub in 6 intensive care units in Colombia. Am J Infect Control. 2011;39(8):633-9.

23. Brasil. Ministério da Saúde; Agência Nacional de Vigilância Sanitária. Resolução Diretoria Colegiada n. 42 , de 25 de outubro de 2010. Dispõe sobre a obrigatoriedade de disponibilização de preparação alcoólica para fricção antisséptica das mãos, pelos serviços de saúde do País, e dá outras providências [Internet]. Brasília; 2010 [citado 2016 abr. 22]. Disponível em: http://bvsms.saude.gov.br/bvs/saudelegis/ anvisa/2010/res0042_25_10_2010.html

24. Boog MC, Erasmus V, Graaf J, HE van Beeck EA, Melles M, van Beeck EF. Assessing the optimal location for alcohol-based hand rub dispensers in a patient room in an intensive care unit. BMC Infect Dis. 2013;13:510. 